\title{
Role of bacterial overgrowth in the stomach as an additional risk factor for gastritis
}

\author{
Gregory Naylor MRCP, Anthony Axon MD FRCP
}

G Naylor, A Axon. Role of bacterial overgrowth in the stomach as an additional risk factor for gastritis. Can J Gastroenterol 2003;17(Suppl B):13B-17B.

Gastric bacteria can either be ingested or ascend from the distal bowel; however, their survival is usually limited by gastric acidity and motility. A reduction in gastric acid can result in bacterial overgrowth in the stomach and proximal small bowel, and the number of organisms rises as the intragastric $\mathrm{pH}$ rises.

The increased risk of noncardia gastric cancer seen in patients with hypochlorhydria may be explained by an excess of nitrites and $\mathrm{N}$-nitroso compounds (NOCs). These compounds are found in the diet of populations with a high gastric cancer risk, but can also be produced by the organisms that exist in the hypochlorhydria stomach. It has long been hypothsized that nitrites and NOCs act as one of the triggers in the atrophy-metaplasia-dysplasia-carcinoma path. However, although indirect data have linked the premalignant changes of metaplasia and dysplasia to NOCs, direct measurement of gastric nitrites and NOCs has not confirmed such a link.

The role of Helicobacter pylori in bacterial overgrowth is mainly as a cause of hypochlorhydria resulting from atrophic gastritis, leading to a reduction in the parietal cell mass.

Acid-suppressing drugs can result in bacterial overgrowth and increased nitrites and NOCs, although there is no current evidence for an increased risk of gastric cancer in patients taking them. One explanation is that the stomach appears to be colonized by different organisms than those in patients with hypochlorhydria for other reasons. There is some evidence that bacterial overgrowth per se can cause gastric inflammation in mice; however, although in humans the degree of gastric inflammation is greater when overgrowth is more prominant this may simply reflect the greater degree of hypochlorhydria in patients with a more severe $\mathrm{H}$ pylori-induced inflammation.

Key Words: Bacterial overgrowth; Gastritis; Hypochlorhydria; N-nitroso compounds.

\section{Rôle de la prolifération bactérienne dans l'estomac : facteur de risque supplémentaire de gastrite}

La présence de bactéries dans l'estomac peut s'expliquer par leur ingestion ou leur remontée à partir de l'intestin distal, mais leur survie est généralement limitée par l'acidité ou la motilité gastriques. Toutefois, une diminution de l'acidité gastrique peut entrainer une prolifération de bactéries dans l'estomac et l'intestin grêle proximal, et le nombre de micro-organismes croît à mesure que s'élève le $\mathrm{pH}$ intragastrique.

L'augmentation du risque de cancer de l'estomac épargnant le cardia observé chez les patients atteints d'hypochlorhydrie peut s'expliquer par un surplus de nitrites et de composés $\mathrm{N}$-nitroso (CNO). Ces composés se trouvent dans l'alimentation des populations ayant un risque élevé de cancer de l'estomac, mais ils peuvent également être produits par des micro-organismes qui survivent en milieu hypochlorhydrique. On croit, depuis longtemps, que les nitrites et les $\mathrm{CNO}$ agissent comme facteurs déclenchants dans la voie atrophie-métaplasie-dysplasie-carcinome. Toutefois, même si des données indirectes ont établi des liens entre les stades précancéreux que sont la métaplasie et la dysplasie, et ces composés, les mesures directes de nitrites et de CNO dans l'estomac, elles, n'ont pas permis d'établir ce type de lien.

Le rôle d'Helicobacter pylori dans la prolifération bactérienne constitue une des principales causes d'hypochlorhydrie attribuable à la gastrite atrophique, qui aboutit à une diminution de la masse cellulaire pariétale. Les antiacides peuvent engendrer une prolifération bactérienne et accroître la présence de nitrites et de $\mathrm{CNO}$, mais aucune donnée jusqu'à maintenant ne fait état d'un risque accru de cancer de l'estomac chez les patients qui en font usage. Une des explications serait que l'estomac semble colonisé par des germes différents de ceux observés chez les patients atteints d'hypochlorhydrie pour d'autres raisons. D'après certaines données, la prolifération bactérienne en soi peut causer une inflammation de l'estomac chez les souris; cependant, même si chez les humains un degré plus élevé d'inflammation de l'estomac est associé à une prolifération plus marquée, cela peut n'être que le reflet du degré supérieur d'hypochlorhydrie chez les patients souffrant d'une inflammation plus intense, causée par $H$ pylori.
$\mathrm{B}_{\mathrm{u}}^{\mathrm{a}}$ acterial colonization of the upper gastrointestinal tract is usually prevented by a combination of acid secretion and intestinal motility. The upper gastrointestinal tract normally has less than $10^{4}$ colony forming units $(\mathrm{CFU}) / \mathrm{mL}$ and 'bacterial overgrowth' has been defined as counts of more than $10^{5} \mathrm{CFU} / \mathrm{mL}$ (1).

There are three possible sources of bacteria in the gastric lumen. They can be ingested with food, originate from the oropharyngeal cavity, or migrate from the small or large bowel and enter the stomach by enterogastric reflux. There is a large variation in the ability of different organisms to survive in the acidic environment of the stomach (2). Most enteric pathogens have the ability to survive in an acidic environment to some extent. Helicobacter pylori (3) occupies a specific niche because it is able to colonize the stomach by using urease to produce an alkaline buffer zone of ammonia around itself. Yersinia enterocolitica also possesses a urease gene and can increase urease production as the $\mathrm{pH}$ decreases (4). Escherichia

This article was originally presented at a conference entitled "Helicobacter pylori: Basic Mechanisms to Clinical Cure 2002", sponsored by Axcan Pharma, November 10-14, 2002, Maui, Hawaii

Centre for Digestive Diseases, Department of Gastroenterology, The General Infirmary at Leeds, Leeds, United Kingdom

Correspondence: Dr Anthony Axon, Centre for Digestive Diseases, Department of Gastroenterology, Room 190A, Clarendon Wing, The General Infirmary at Leeds, Great George Street, Leeds, LS1 3EX, United Kingdom. Telephone +44-113-392-2125,

fax+44-113-392-6968, e-mail anthony.axon@leedsth.nhs.uk 
TABLE 1

COPYRIGHT PULSUS GROUP INC, " DO NOT COPY

Studies of bacterial overgrowth, nitrite increase and nitrosation following treatment with acid-inhibitory drugs

\begin{tabular}{|c|c|c|c|c|c|c|}
\hline Year (reference) & $\begin{array}{l}\text { Number } \\
\text { in study }\end{array}$ & Acid-inhibitory drug & Bacteria in gastric juice & $\begin{array}{l}\text { Bacteriology } \\
\text { test }\end{array}$ & Nitrite & Nitrosamine \\
\hline $1980(11)$ & 31 & Cimetidine & Increase & Culture & $\mathrm{NE}$ & $\mathrm{NE}$ \\
\hline $1981(48)$ & 407 & Cimetidine & Increase & Culture & Increase & Increase \\
\hline $1982(44)$ & 23 & Cimetidine $1 \mathrm{~g}$ daily & Increase & Culture & Increase & Increase \\
\hline $1982(50)$ & 8 & Cimetidine & Increase (resembling mouth flora) & Culture & NE & NE \\
\hline $1984(51)$ & 30 & Cimetidine 400 mg BD & No evidence of bacterial overgrowth & $\mathrm{H}_{2}$ breath test & NE & NE \\
\hline $1984(52)$ & 4 & Ranitidine & Increase (not nitrate reducing) & Culture & No increase & No increase \\
\hline $1984(12)$ & 10 & Omeprazole 30 mg daily & Increase & Culture & Increase & Increase \\
\hline $1994(53)$ & 14 & Omeprazole 20 mg daily & Increase & Culture & Increase & Increase \\
\hline $1996(14)$ & 47 & $\begin{array}{l}\text { Cimetidine } 800 \mathrm{mg} \text { or } \\
\text { omeprazole } 20 \mathrm{mg} \text { daily }\end{array}$ & $\begin{array}{l}\text { Increase in bacteria in gastric juice } \\
\text { in } 53 \% \text { omeprazole, } 17 \% \text { cimetidine }\end{array}$ & Culture & No increase & No increase \\
\hline $1996(54)$ & 73 & Cimetidine & Increase & Culture & NE & $\mathrm{NE}$ \\
\hline $2000(55)$ & 14 & Omeprazole 20 mg daily & Increase & Culture & Increase & No increase \\
\hline $2000(31)$ & 29 & Omeprazole & Increase & Culture & Increase & NE \\
\hline
\end{tabular}

BD Twice daily; NE Not examined

coli and Shigella flexneri can both survive exposure to a $\mathrm{pH}$ of 2.0 to 2.5. Salmonella typhimurium will not normally tolerate a $\mathrm{pH}$ of 3 but is able to mount an acid tolerance response that allows it to adapt and multiply at a lower $\mathrm{pH}$ (5). Differences in the ability to cope with an acidic environment may account for the infective dose of such enteric pathogens as $S$ typhimurium being $10^{5}$ organisms while $S$ flexneri may only need 10 organisms to be ingested. As the $\mathrm{pH}$ rises, so does the number of organisms. Gastric colonization is proportional to both the $\mathrm{pH}$ and the time spent above a $\mathrm{pH}$ of $3.8(6,7)$.

Bacterial overgrowth is associated with an increased risk of noncardia gastric cancer as seen in patients with hypochlorhydria due to pernicious anemia (8), atrophic gastritis (9) or partial gastrectomy (10). The principal hypothesis of carcinogenesis is based on evidence that bacterial overgrowth results in the production of nitrite from nitrate with subsequent production of carcinogenic N-nitroso compounds (NOCs). The purpose of the present review is to explore the relationship between bacterial overgrowth and gastric mucosal inflammation.

\section{CAUSES OF BACTERIAL OVERGROWTH}

Reduction in gastric acid from any cause may result in bacterial overgrowth in the stomach and the small intestine. Autoimmune gastritis resulting from the production of parietal cell antibodies in pernicious anemia is the classical natural cause. Distal gastrectomy (removing the gastrin-producing $\mathrm{G}$ cells of the antrum) can also result in bacterial overgrowth. The introduction of pharmacological acid suppression, initially with $\mathrm{H} 2$ receptor antagonists (11) and more recently with proton pump inhibitors (PPIs) (12), induces bacterial colonization of the stomach (Table 1). However, chronic infection with $\mathrm{H}$ pylori resulting in gastric atrophy and loss of parietal cell mass is the most common cause of hypochlorhydria and/or achlorhydria worldwide.

There appears to be a difference between the organisms found in the stomachs of patients with reduced acid due to autoimmune gastritis compared with those taking acid suppressing medication. In the former, coliforms predominate, while in the latter, Gram-positive organisms are found. The reasons for this are not clear but could relate to the shorter history of hypochlorhydria in acid suppression leading to colonization by organisms swallowed from the oropharynx $(13,14)$.
H pylori status also appears to affect the degree of bacterial colonization (of non-Helicobacter species), especially in patients taking a PPI. H pylori-infected patients taking a PPI show a greater degree of colonization than do patients who are H pylori-negative. This is discussed in detail below.

\section{CONSEQUENCES OF GASTRIC COLONIZATION}

Enhanced nitrite production

Nitrites are required for the production of NOCs and can originate from three potential sources. They can be found in many foods such as cured meats, baked foods and cereals, while buccal and gastric bacteria can also convert dietary and/or salivary nitrate to nitrite. Twenty-five per cent of absorbed nitrate is secreted in the saliva and $40 \%$ of this is reduced to nitrite in the mouth. This appears to be due to reducing bacteria found in deep clefts at the back of the tongue. Swallowed nitrates can also be reduced to nitrites in the gastric lumen by colonizing bacteria. As the $\mathrm{pH}$ rises, the role of gastric bacteria as nitrite producers becomes more important, contributing $90 \%$ of nitrite load in a hypochlorhydria patient (15), and nitrite levels in gastric juice are also increased in these patients (16). Studies measuring gastric nitrite indirectly suggested a link between high concentrations of nitrite in gastric juice with an increased risk of gastric metaplasia, dysplasia and carcinoma, although this has not actually been confirmed by direct measurement (17). However, the persistence of nitrites in the stomach is dependent on the intragastric $\mathrm{pH}$ and the presence of ascorbic acid. At an acid $\mathrm{pH}$ and with ascorbic acid present, nitrites are rapidly reduced to nitric oxide, which can be detected in gas from the stomachs of individuals with normal acid secretion (18). Ascorbic acid is actively secreted by healthy gastric mucosa; however, its secretion is reduced in hypochlorhydric gastric juice. Hence, nitrites will persist because both of the factors needed for their conversion to nitric oxide (ascorbic acid and gastric acid) are decreased.

\section{Production of NOCs}

NOCs are composed of nitrosamides $\left(\mathrm{R}_{1} \mathrm{NNO} \cdot \underline{\mathrm{COR}} \mathrm{R}_{2}\right)$ and nitrosamines $\left(\mathrm{R}_{1} \mathrm{NNOR}_{2}\right)$. They are recognized carcinogens in animals and can induce gastric cancer in rodents. They can be formed in the gastric lumen from the nitrosation of primary, secondary and tertiary amines, amino acids, peptides, amides, imides, bile acids, guanidines and urea. 
Correa's hypothesis of gastric carcinogenesis was based on epidemiological studies identifying achlorhydria and/or hypochlorhydria $(19,20)$, diets high in nitrate or nitrite and low in vitamin $\mathrm{C}(21-26)$, and H pylori infection $(27,28)$ as risk factors for cancer of the mid and distal stomach.

\section{$H$ pylori colonization and bacterial overgrowth}

The role of $H$ pylori infection in bacterial overgrowth is complex. Acid suppression allows $H$ pylori gastritis to spread from the antrum to the corpus. Inflammation of the corpus reduces parietal cell function further and can eventually lead to atrophy of the corpus mucosa and a permanent reduction in acid-producing capability or even achlorhydria. Mowat et al (29) studied the effect of $\mathrm{H}$ pylori status on $\mathrm{pH}$ and bacterial overgrowth during omeprazole treatment in 29 healthy volunteers. They simultaneously studied the effect of $\mathrm{H}$ pylori status on gastric ascorbic acid and nitrite levels during omeprazole treatment in a further 22 healthy volunteers. They concluded that acid suppression is more marked, bacterial overgrowth is greater, postmeal nitrite levels are higher and ascorbic acid levels are lower in $\mathrm{H}$ pyloripositive compared with negative patients. They found predominantly oropharyngeal organisms, some of which were capable of reducing nitrate to nitrite and of synthesizing NOCs.

$H$ pylori infection can result in atrophic gastritis with an increased risk of gastric cancer. Whether this is due to a direct effect of the organism, a result of NOCs from bacterial overgrowth or a combination of the two is not yet known. H pylori infection has, however, been shown to enhance the carcinogenicity of nitrosamines in rodent models (30). Given the combination of bacterial overgrowth and gastric inflammation present in the stomach of $\mathrm{H}$ pylori-positive patients taking PPIs, there is some concern about the long term risks of gastric cancer, which are discussed below.

There does not appear to be a link between NOCs and premalignant changes in the gastric mucosa. Intestinal metaplasia is a precursor for gastric cancer and is known to be associated with $H$ pylori infection, low ascorbic acid levels and bile reflux. However, intestinal metaplasia is not associated with elevated gastric nitrite or total NOC (17) and, at present, it appears that NOCs are pure carcinogens and do not contribute to 'precancerous' mucosal changes.

\section{Acetaldehyde production and bacterial overgrowth}

Acetaldehyde (31) is a known carcinogen (32). Bacterial overgrowth in the hypochlorhydric stomach enhances the production of acetaldehyde from ethanol after ingestion. Acetaldehyde levels are also higher in alcohol dehydrogenase deficient individuals (common in the Far East). Alcohol does not necessarily need to be ingested because bacterial and yeast overgrowth can result in endogenous ethanol production.

Treatment with a PPI increases acetaldehyde production from ethanol in the gastric juice, probably as a result of bacterial overgrowth. Several organisms are associated with acetaldehyde production, including Neisseria, Stomatococcus and Streptococcus species. Therefore, acetaldehyde could be considered together with NOCs as potential gastric carcinogens.

\section{Effects of bacterial overgrowth on the gastric mucosa}

The reduction of nitrates to nitrites and the subsequent production of NOCs has been the principal focus of the effect of bacterial overgrowth in the stomach. Could bacterial overgrowth affect the gastric mucosa by any other mechanisms?
Zavros et al (33), using a mouse model, studied wild type (gastrin secreting $[\mathrm{G}+]$ ) and genetically achlorhydric (nongastrin secreting $[\mathrm{G}-]$ ) mice. Initial assessment of gastric pathology in both groups revealed greater inflammation in the $\mathrm{G}-$ mice. There were also higher bacterial counts in the antrum of Gmice than in $\mathrm{G}+$ mice. Groups of both genotypes were then treated with antibiotics until the feces showed no bacterial growth. The gastritis was then reassessed and found to have resolved in the G- mice. Treatment of the $\mathrm{G}+$ mice with omeprazole led to an increase in bacterial count and an increase in gastritis that was reduced by subsequent antibiotic treatment (33). The bacterial species were typed and found to be similar in both genotypes. No H pylori or other ureaseproducing Helicobacter species were present and, hence, could not be a cause of the inflammation.

The authors concluded that bacterial overgrowth contributed to the inflammatory response in the stomach. It was noted that in both genetically and pharmacologically induced hypochlorhydria gastritis increased as bacterial overgrowth increased. However, there was a discrepancy in the magnitude of change of inflammation compared with the magnitude of change of bacterial numbers. This suggested that other factors, perhaps those related to bacterial metabolism, contributed to the degree of inflammation. Because NOCs were not measured, it is difficult to assess their role in this scenario, although there is no other evidence that they are pro-inflammatory.

If bacterial overgrowth contributes to inflammation in humans, we would expect to see evidence of it in patients receiving PPI treatment. Kuipers et al (34) studied the incidence of atrophic gastritis in $H$ pylori-positive and negative gastroesophageal reflux patients treated with PPI or antireflux surgery. H pylori-negative patients were found to have a mild gastritis in seven of 46 patients before PPI treatment. After a mean follow-up of five years, moderate to severe corpus gastritis had developed in only two patients (4\%). This was associated with atrophy and corresponded to an annual increase of $0.8 \%$. There was no evidence of intestinal metaplasia. In comparison, the incidence of gastritis in the PPI-treated H pyloriinfected group increased from $59 \%$ to $81 \%$ and atrophy from $0 \%$ to $31 \%$. In the $H$ pylori-negative surgical group, there was no evidence of inflammation or atrophy before treatment or after a mean follow-up of five years. The $H$ pylori-positive surgical cohort showed no change in prevalence or severity of gastritis, and none of the patients developed atrophy. Is the $4 \%$ incidence of gastritis in the $\mathrm{H}$ pylori-negative PPI cohort evidence that bacterial overgrowth induces gastritis?

A study by Lundell et al (35) did not find any association between $H$ pylori infection, PPI treatment and the development of gastric atrophy. There was no evidence of gastric inflammation in the $H$ pylori-negative group either before or after treatment. There was a trend to atrophy in the $H$ pylori-positive group that did not reach statistical significance, but other studies support Kuipers' results, suggesting an annual incidence of atrophy of $3.8 \%$ to $8.7 \%(35-40)$. Klinkenberg-Knol et al (36, 37) found an annual incidence of atrophy of $0.7 \%$ in $\mathrm{H}$ pylorinegative subjects on PPI treatment $(4.7 \%$ in $\mathrm{H}$ pylori-positive subjects). There was an associated increase in the severity of gastritis in this cohort but the exact numbers are not given in the published results. These data suggest that severe gastric inflammation with associated atrophy occurs in less than $1 \%$ per year in $\mathrm{H}$ pylori-negative patients treated with a PPI. This does not support the hypothesis proposed by the Zavros et al (33) study, 
which showed, in mice, that bacterial overgrowth alone can result in gastric inflammation.

Sanduleanu and colleagues $(41,42)$ have addressed this issue in two papers. They have shown that non-H pylori flora (both lumenal and mucosally associated) was significantly increased in those patients on acid suppression therapy who were infected with Helicobacter species than those who were not. In their second paper, they showed that the simultaneous presence of $\mathrm{H}$ pylori and non-H pylori bacteria was associated with a 20-fold increased risk of developing atrophic gastritis, suggesting a synergistic effect between the two infections. The weakness of their hypothesis, however, is that the greater the atrophy, the lower will be the acid secretion and, consequently, the greater the bacterial overgrowth. In other words, the increased bacterial overgrowth may reflect the higher degree of atrophy rather than vice versa. Nevertheless, the hypothesis is interesting and more research is needed in this area.

\section{Bacterial overgrowth and bile acid metabolism}

Bile reflux into the stomach is associated with an increased incidence of intestinal metaplasia (43). Some species of bacteria colonizing the stomach and small intestine during bacterial overgrowth are capable of deconjugating bile acids. Much of the attention has been focused on the role that bile plays in gastroesophageal reflux disease. The concentration of bile acids reaching the esophagus and their toxic effects are known to vary with $\mathrm{pH}$ depending on the degree of ionization (44). Unconjugated bile acids tend to precipitate in solutions with a

\section{REFERENCES}

1. Evenepoel P. Alteration in digestion and absorption of nutrients during profound acid suppression. Best Pract Res Clin Gastroenterol 2001;15:539-51.

2. Howden CW, Hunt RH. Relationship between gastric secretion and infection. Gut 1987;28:96-107.

3. Marshall BJ, Barrett LJ, Prakash C, McCallum RW, Guerrant RL. Urea protects Helicobacter (Campylobacter) pylori from the bactericidal effect of acid. Gastroenterology 1990;99:697-702.

4. Young GM, Amid D, Miller VL. A bifunctional urease enhances survival of pathogenic Yersinia enterocolitica and Morganella morganii at low pH. J Bacteriol 1996;178:6487-95.

5. Lin J, Lee IS, Frey J, Slonczewski JL, Foster JW. Comparative analysis of extreme acid survival in Salmonella typhimurium, Shigella flexneri, and Escherichia coli. J Bacteriol 1995;177:4097-104.

6. Gray JD, Shiner M. Influence of gastric $\mathrm{pH}$ on gastric and jejunal flora. Gut 1967;8:74-81.

7. Theisen J, Nehra D, Citron D, et al. Suppression of gastric acid secretion in patients with gastroesophageal reflux disease results in gastric bacterial overgrowth and deconjugation of bile acids. J Gastrointest Surg 2000;4:50-4.

8. Hsing AW, Hansson LE, McLaughlin JK, et al. Pernicious anemia and subsequent cancer. A population-based cohort study. Cancer 1993;71:745-50.

9. Namekata T, Miki K, Kimmey M, et al. Chronic atrophic gastritis and Helicobacter pylori infection among Japanese Americans in Seattle. Am J Epidemiol 2000;151:820-30.

10. Lundegardh G, Adami HO, Helmick C, Zack M, Meirik O. Stomach cancer after partial gastrectomy for benign ulcer disease. N Engl J Med 1998;319:195-200.

11. Ruddell WS, Axon ATR, Findlay JM, Bartholomew BA, Hill MJ. Effect of cimetidine on the gastric bacterial flora. Lancet 1980;1:672-4.

12. Sharma BK, Santana IA, Wood EC, et al. Intragastric bacterial activity and nitrosation before, during, and after treatment with omeprazole. Br Med J (Clin Res Ed) 1984;289:717-9.

13. Fried M, Siegrist H, Frei R, et al. Duodenal bacterial overgrowth during treatment in outpatients with omeprazole. Gut 1994;35:23-6.

14. Thorens J, Froehlich F, Schwizer W, et al. Bacterial overgrowth during treatment with omeprazole compared with cimetidine: a prospective randomised double blind study. Gut 1996;39:54-9.
$\mathrm{pH}$ lower than 4. Esophageal perfusion studies in animal models have shown that unconjugated bile acids can cause mucosal damage in alkaline solutions $(45,46)$; however, no equivalent data exist for the effect of unconjugated bile acids on the gastric mucosa. Bile acids can also act as a substrate for nitrosation to produce NOCs and there is evidence of genotoxicity from these products (47).

\section{CONCLUSION}

Non-H pylori bacterial colonization of the stomach occurs when the $\mathrm{pH}$ of the gastric juice rises. The number of bacteria present increases as the $\mathrm{pH}$ increases, and the resulting organisms can be of oropharyngeal or fecal origin. Decreased gastric acid secretion for any reason can lead to bacterial overgrowth; both $\mathrm{H} 2$ receptor antagonists and PPIs are known to cause it. Many organisms metabolize nitrate to nitrite and others are capable of inducing nitrosation to NOCs. They may also increase acetaldehyde production and deconjugate bile salts. It is unclear whether these metabolic activities or others as yet undefined may increase the gastric inflammatory response in the human hypochlorhydric stomach. There is good evidence that gastric bacterial overgrowth per se causes inflammation in the stomachs of mice, and some data in humans show that the inflammatory response is greater when overgrowth is prominent, but this finding may merely reflect the greater degree of hypochlorhydria in those patients with a more severe $\mathrm{H}$ pyloriinduced inflammation.

15. Eisenbrand G, Adam B, Peter M, Malfertheiner P, Schlag P. Formation of nitrite in gastric juice of patients with various gastric disorders after ingestion of a standard dose of nitrate - a possible risk factor in gastric carcinogenesis. IARC Sci Publ 1984;57:963-8.

16. Ruddell WSJ, Bone ES, Hill MJ, Blendis LM, Walters CL. Gastric juice nitrite: a risk factor for cancer in the hypochlorhydric stomach. Lancet 1976;2:1037-9.

17. Sobala GM, Pignatelli B, Schorah CJ, et al. Levels of nitrite, nitrate, $\mathrm{N}$-nitroso compounds, ascorbic acid and total bile acids in gastric juice of patients with and without precancerous conditions of the stomach. Carcinogenesis 1991;12:193-8.

18. Lundberg JO, Weitzberg E, Lundberg JM, Alving K. Intragastric nitric oxide production in humans: measurements in expelled air. Gut 1994;35:1543-6.

19. Correa P. Human gastric carcinogenesis:a multistep and multifactorial process - First American Cancer Society Award Lecture on Cancer Epidemiology and Prevention. Cancer Res 1992;52:6735-40.

20. Chen VW, Abu-Elyazeed RR, Zavala DE, et al. Risk factors of gastric precancerous lesions in a high-risk Colombian population. II. Nitrate and nitrite. Nutr Cancer 1990;13:67-72.

21. Cuello C, Correa P, Haenszel W, et al. Gastric cancer in Colombia. I. Cancer risk and suspect environmental agents. J Natl Cancer Inst 1976;57:1015-20.

22. Tannenbaum SR, Archer MC, Wishnok JS, et al. Nitrate and the etiology of gastric cancer. In: Hiatt HH, Watson JD \& Winsten JA, eds). Origins of Human Cancer. New York: Cold Spring Harbor Laboratory, 1977:1609-25.

23. Haenszel W, Kurihara M, Segi M, Lee RK. Stomach cancer among Japanese in Hawaii. J Natl Cancer Inst 1972;49:969-88.

24. Graham S, Schotz W, Martino P. Alimentary factors in the epidemiology of gastric cancer. Cancer 1972;30:927-38.

25. Bjelke E. Epidemiologic studies of cancer of the stomach, colon, and rectum; with special emphasis on the role of diet. Scand J Gastroenterol 1974;31(Suppl):1-235.

26. Block G. Vitamin C and cancer prevention: the epidemiologic evidence. Am J Clin Nutr 1991;53(Suppl 1):270S-82S.

27. Parsonnet J, Friedman GD, Vandersteen DP, et al. Helicobacter pylori 
infection and the risk of gastric carcinoma. N Engl J Med 1991;325:1127-31.

28. International Agency for Research on Cancer. Schistosomes, Liver Flukes and Helicobacter pylori. Monograph 61. Lyon, France: IARC, 1994:177-240

29. Mowat C, Williams C, Gillen D, et al. Omeprazole, Helicobacter pylori status, and alterations in the intragastric milieu facilitating bacterial N-nitrosation. Gastroenterology 2000;119:339-47.

30. Sugiyama A, Maruta F, Ikeno T, et al. Helicobacter pylori infection enhances $\mathrm{N}$-methyl-N-nitrosourea-induced stomach carcinogenesis in the Mongolian gerbil. Cancer Res 1998;58:2067-9.

31. Vakevainen S, Tillonen J, Blom M, Jousimies-Somer H Salaspuro M. Acetaldehyde production and other ADH-related characteristics of aerobic bacteria isolated from hypochlorhydric human stomach. Alcohol Clin Exp Res 2001;25:421-6.

32. Blot WJ. Alcohol and cancer. Cancer Res 1992;52(Suppl 7):2119-23.

33. Zavros Y, Rieder G, Ferguson A, Samuelson LC, Merchant JL. Genetic or chemical hypochlorhydria is associated with inflammation that modulates parietal and G-cell populations in mice. Gastroenterology 2002;122:119-33.

34. Kuipers EJ, Lundell L, Klinkenberg-Knol EC, et al. Atrophic gastritis and Helicobacter pylori infection in patients with reflux esophagitis treated with omeprazole or fundoplication. N Engl J Med 1996;334:1018-22.

35. Lundell L, Miettinen P, Myrvold HE, et al. Lack of effect of acid suppression therapy on gastric atrophy. Nordic Gerd Study Group. Gastroenterology 1999;117:319-26.

36. Klinkenberg-Knol EC, Nelis F, Dent J, et al. Long-term omeprazole treatment in resistant gastroesophageal reflux disease:efficacy, safety, and influence on gastric mucosa. Gastroenterology 2000;118:661-9.

37. Klinkenberg-Knol EC, Festen HP, Jansen JB, et al. Long-term treatment with omeprazole for refractory reflux esophagitis: efficacy and safety. Ann Intern Med 1994;121:161-7.

38. Lamberts R, Creutzfeldt W, Struber HG, Brunner G, Solcia E. Long-term omeprazole therapy in peptic ulcer disease: gastrin, endocrine cell growth, and gastritis. Gastroenterology 1993;104:1356-70.

39. Solcia E, Fiocca R, Havu N, Dalvag A, Carlsson R. Gastric endocrine cells and gastritis in patients receiving long-term omeprazole treatment. Digestion 1992;51(Suppl 1):82-92.

40. Kuipers EJ, Lee A, Klinkenberg-Knol EC, Meuwissen SG. Review article: the development of atrophic gastritis - Helicobacter pylori and the effects of acid suppressive therapy. Aliment Pharmacol Ther 1995;9:331-40.

41. Sanduleanu S, Jonkers D, De Bruine A, Hameeteman W, Stockbrugger RW. Non-Helicobacter pylori bacterial flora during acid-suppressive therapy: differential findings in gastric juice and gastric mucosa. Aliment Pharmacol Ther 2001;15:379-88.
42. Sanduleanu S, Jonkers D, De Bruine A, Hameeteman W, Stockbrugger RW. Double gastric infection with Helicobacter pylori and non-Helicobacter pylori bacteria during acid-suppressive therapy: increase of pro-inflammatory cytokines and development of atrophic gastritis. Aliment Pharmacol Ther 2001;15:1163-75.

43. Sobala GM, O'Connor HJ, Dewar EP, King RF, Axon ATR, Dixon MF. Bile reflux and intestinal metaplasia in gastric mucosa. J Clin Pathol 1993;46:235-40.

44. Nehra D, Howell P, Williams CP, Pye JK, Beynon J. Toxic bile acids in gastro-oesophageal reflux disease: influence of gastric acidity. Gut 1999;44:598-602.

45. Kivilaakso E, Fromm D, Silen W. Effect of bile salts and related compounds on isolated esophageal mucosa. Surgery 1980;87:280-5.

46. Lillemoe KD, Johnson LF, Harmon JW. Role of the components of the gastroduodenal contents in experimental acid esophagitis. Surgery 1982;92:276-84.

47. Puju S, Shuker DE, Bishop WW, Falchuk KR, Tannenbaum SR, Thilly WG. Mutagenicity of $\mathrm{N}$-nitroso bile acid conjugates in Salmonella typhimurium and diploid human lymphoblasts. Cancer Res 1982;42:2601-4.

48. Reed PI, Smith PL, Haines K, House FR, Walters CL. Effect of cimetidine on gastric juice $\mathrm{N}$-nitrosamine concentration. Lancet 1981;2:553-56.

49. Stockbrugger RW, Cotton PB, Eugenides N, Bartholomew BA, Hill MJ, Walters CL. Intragastric nitrites, nitrosamines and bacterial overgrowth during cimetidine treatment. Gut 1982;23:1048-54.

50. Snepar R, Poporad GA, Romano JM, Kobasa WD. Kaye D. Effect of cimetidine and antacid on gastric microbial flora. Infect Immun 1982;36:518-24.

51. Milton-Thompson GJ, Lightfoot NF, Ahmet Z, et al. Intragastric acidity, bacteria, nitrite and $\mathrm{N}$-nitroso compounds before, during and after cimetidine treatment. Lancet 1982;1:1091-5.

52. Garcia del Risco F, Rolin O, Farinotti R, et al. Influence of ranitidine during a 24-hour period on the level of nitrites, nitrates, nitrosamines and bacterial flora in the gastric juice of healthy subjects. Gastroenterol Clin Biol 1984;8:749-53.

53. Verdue E, Viani F, Armstrong D, et al. Effect of omeprazole on intragastric bacterial counts, nitrates, nitrites and $\mathrm{N}$-nitroso compounds. Gut 1994;35:455-60.

54. Shindo K, Yamazaki R, Koide K, Fukumura M, Hirai Y. Alteration of bile acid metabolism by cimetidine in healthy humans. J Invest Med 1996;44:462-9.

55. Viani F, Siegrist HH, Pignatelli B, et al. The effect of intra-gastric acidity and flora on the concentration of $\mathrm{N}$-nitroso compounds in the stomach. Eur J Gastroenterol Hepatol 2000;12:165-73. 


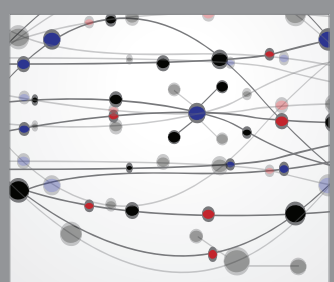

The Scientific World Journal
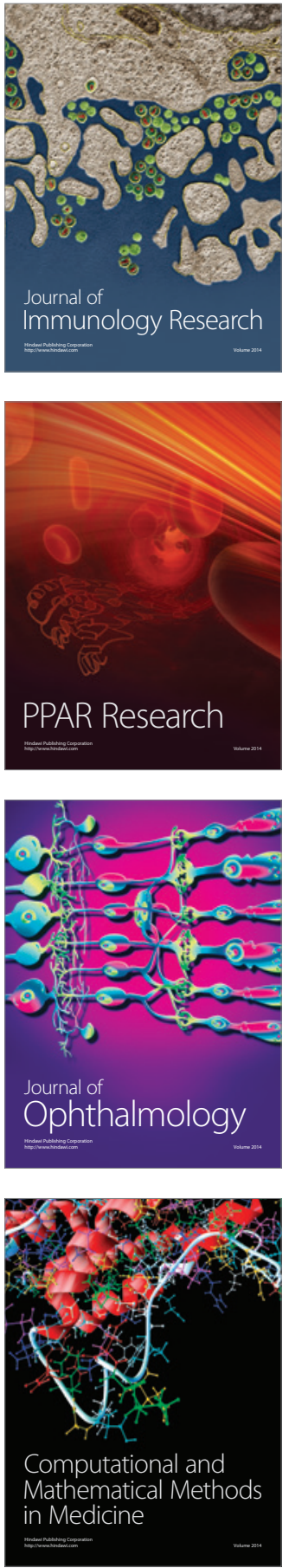

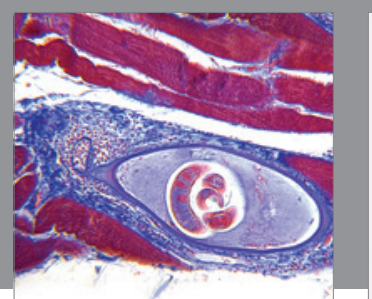

Gastroenterology Research and Practice

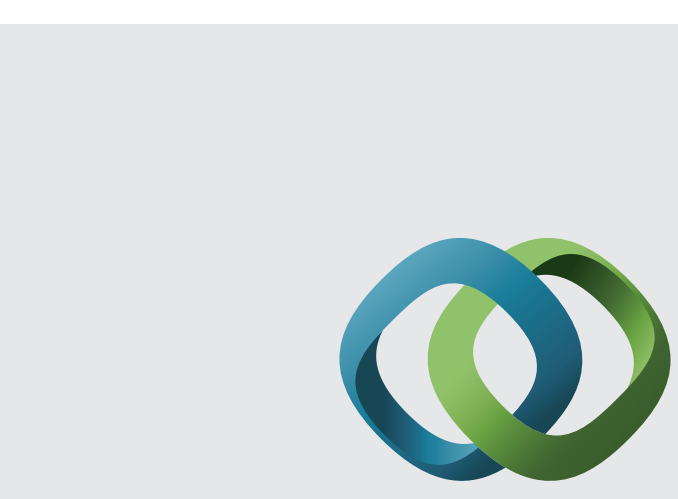

\section{Hindawi}

Submit your manuscripts at

http://www.hindawi.com
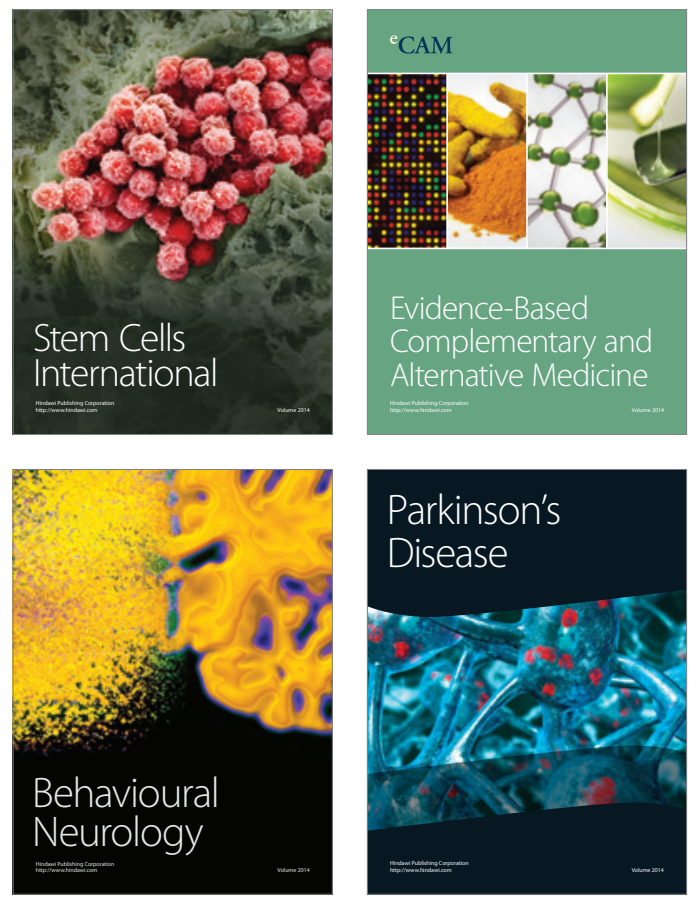
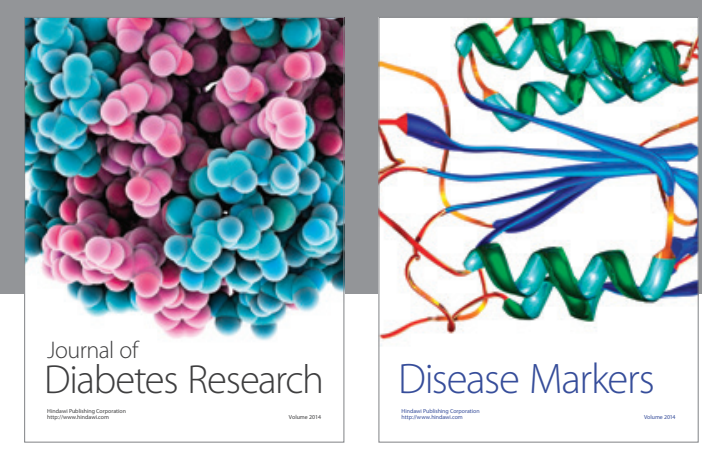

Disease Markers
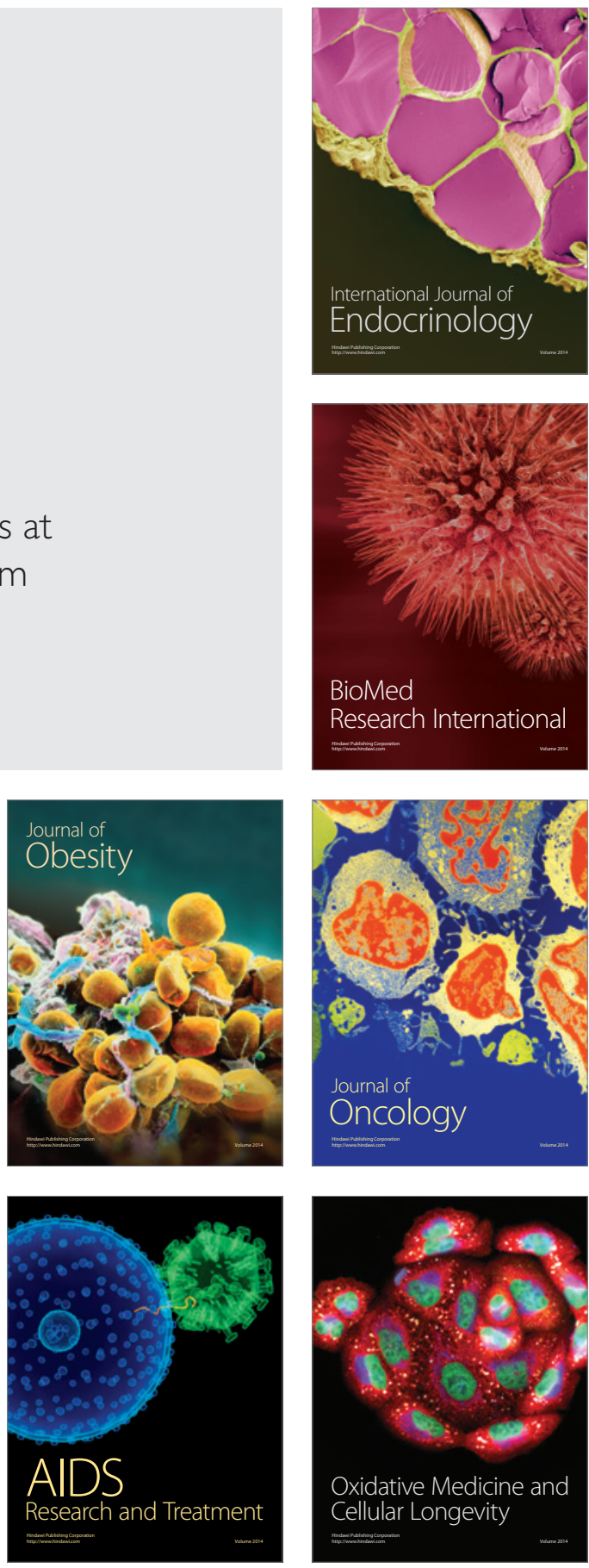